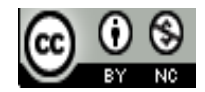

Jurnal Bimbingan Konseling Indonesia is licensed under

A Creative Commons Attribution-Non Commercial 4.0 International License.

\title{
MODEL INTEGRATED COUNSELING PROBLEM SOLVING MAHASISWA BERBASIS LAYANAN SISTEM INFORMASI
}

\author{
Sudarmaji ${ }^{1)}$, Hadi Pranoto ${ }^{2)}$ \\ ${ }^{1)}$ Universitas Muhammadiyah Metro, Metro Lampung Indonesia \\ E-mail: majidarma5022@gmail.com \\ ${ }^{2)}$ Universitas Muhammadiyah Metro, Metro Lampung Indonesia \\ E-mail: hadipranoto21@gmail.com
}

\begin{abstract}
Abstrak. Studi ini meneliti tentang model integrasi konseling problem solving mahasiswa berbasis sistem informasi. Penelitian ini bertujuan untuk mengetahui 1) Gambaran yang dialami subjek dari dua program studi, 2) Dampak psikologi yang dirasakan subjek, 3) Pengaruh konseling problem solving mahasiswa terhadap pemecahan masalah subjek. Subjek penelitian ini terdiri atas 20 mahasiswa 10 Mahasiswa Bimbingan dan Konseling dan 10 Mahasiswa Imu Komputer masing-masing memiliki latar belakang permasalahan yang berbeda. Subjek tujuan tersebut mempunyai permasalahan dan dengan keikhlasan hati untuk dapat menuangkan ke dalam forum layanan konseling mahasiswa berbasis sistem informasi. Metode dalam penelitian ini adalah Mix Method dengan Rancangan Metode Campuran Convergen. Pengambilan data dilakukan dengan menggunakan sistem informasi layanan konseling mahasiswa dengan penanganan secara langsung oleh dosen yang ditugaskan. Data kemudian diolah dengan menggunakan kaedah-kaedah penelitian kualitatif. Hasil analisis menunjukkan bahwa ketiga subjek memberikan respon positif terhadap konseling mahasiswa berbasis sistem informasi. Ketiga subjek mengakui bahwa konseling layanan berbasis sistem informasi memberikan solusi atas permasalahan mahasiswa alami. Ini menunjukkan bahwa sistem layanan konseling mahasiswa dengan menggunakan teknologi memberikan pengaruh terhadap pemecahan masalah, disamping itu mahasiswa lebih nyaman dalam menyampaikan permasalahan yang tengah dihadapi.
\end{abstract}

Kata Kunci: Model Integrated; Konseling; Problem Solving; Sistem Informasi

\section{Pendahuluan}

Manusia adalah makhluk yang sangat sempurna diantara mahluk lainnya, dibuktikan lewat beragam kajian tentang manusia dalam berbagai perspektif, baik normatif, filosofis maupun empirik. Para ahli meneliti hakikat manusia, mulai dari penciptaan manusia, dimensi fisik dan psikisnya, karya dan dampaknya, serta masalah dirinya, masyarakat dan lingkungan hidupnya. Beragam sebutan diberikan kepada manusia seperti yang dituangkan misalnya homo sapiens (manusia berakal), homo economics (manusia ekonomi), dan economical animal (binatang ekonomi) [1].

Ketika menjalani hidup sehari-hari, manusia tidak selamanya dalam kondisi bahagia. Namun kadang mengalami musibah, nikmat, susah, senang, sedih bahkan terkadang merasakan kesuksesan di luar rencana. Dalam hal rasa, manusia mempunyai interpretasi berbeda-beda tentang apa yang dirasakan hati. Meskipun demikian, manusia telah dianugerahi sejumlah potensi yaitu jasmani, akal dan rohani. Dengan mendayagunakan ketiga potensi tersebut, idealnya manusia akan mampu menyelesaikan seluruh problem kehidupannya. Namun, semua potensi tersebut tidak memiliki arti apa pun, manakala manusia tersebut tidak memiliki kemampuan dalam memecahkan masalah (problem solving). Masalah adalah sesuatu yang harus dipecahkan atau dicarikan jalan keluarnya. Ada pula yang mengartikan masalah sebagai suatu kesenjangan antara apa yang seharusnya dengan apa yang Terjadi. barangkali kedua pernyataan itu lebih tepat. Apa yang terjadi bisa saja lebih positif atau menguntungkan dari apa yang seharusnya. karena sering kali masalah adalah sesuatu yang dianggap apa yang terjadi lebih negatif atau merugikan dari apa yang seharusnya. tapi bagaimana untuk menanggulangi kedua masalah (positif dan negatif) tersebut? 
perspektif suatu alat pemecahan masalah yang dapat kita gunakan pada masalah sederhana ataupun kompleks, di rumah atau di kantor. solusi pemecahan masalah yang praktis untuk digunakan dan sederhana untuk dimengerti harus ada dan perlu kita ketahui di kehidupan sekarang yang semakin kompleks. [2]

Problem solving merupakan proses yang memerlukan penalaran, berpikir kreatif, dan pengetahuan formal seseorang untuk menyelesaikan masalah. Faktor-faktor yang memengaruhi seseorang dalam menyelesaikan masalah antara lain adalah tingkat perkembangan peserta didik, pengetahuan dasar, faktor psikologis, jenis masalah, serta analisis masalah secara mendalam dan komprehensif [3].

Namun terkadang manusia sulit dalam memecahkan masalah yang ada, karena tidak berani dalam mengungkapkan secara langsung. Dengan perkembangan teknologi sistem informasi yang semakin baik, layanan konseling berbasis sistem informasi dapat membantu dalam menyelesaikan problem solving individu. Perkembangan jaman, terutama pada jaman modern ini, banyak menimbulkan perubahan dan kemajuan-kehidupan dalam masyarakat. Disamping itu pertambahan penduduk yang kian hari kian meningkat cukup banyak berpengaruh terhadap perkembangan kehidupan. Keadaan seperti diatas itu akan menantang individu untuk dapat menyesuaikan diri di era modernisasi saat ini. Perubahandan perkembangan tersebutakan mengakibatkan bertambahnya jenis-jenis pekerjaan dimasyarakat, bertambahnya jenis-jenis pendidikan, pola kehidupan,dan sebagainya. Dengan demikian setiap individu akan menghadapi berbagai masalah, seperti masalah penyesuaian diri, self introvet, permasalahan keluarga, permasalahan perekonomian, permasalahan belajar, permasalahan berhubungan dengan lawan jenis, dalam permasalahan tersebut mahasiswa membutuhkan proses konsultasi yang disebut dengan proses konseling antara mahasiswa dan dosen. Dimana kita ketahui bersama konseling adalah proses wawancara/interview yang bersifat memecahkan permasalahan konseli/klien diharapkan mereka dapat secara mandiri memecahakan permasalahan mereka sendiri dan keputusan terbaik ada di tangan konseli tersebut.

Menurut [4], dalam melaksanakan layanan konseling individu, guru BK harus mampu menerapkan dan menguasai keterampilan dasar konseling karena dapat sedikit banyak menjamin keberlangsungan suatu proses konseling untuk mencapai tujuan konseling. Dan poin terpenting dalam proses konseling ini adalah memandirikan klien/ konseli/ peserta didik yang memiliki masalah, sehingga dia memiliki pemecahan masalah secara mandiri (Self Problem Solving) [4].

Istilah teknologi informasi (Information Technology) atau IT mulai popular di akhir dekade 70an. Pada masa sebelumnya, istilah teknologi komputer atau pengolahan data elektronik atau PDE (Elektronic Data Processing) atau EDP lebih dikenal. Sistem Informasi melibatkan komputer disebut sistem informasi berbasis komputer, kemudian berkembang pengolahan sistem informasi dengan istilah SIM (Sistem Informasi Manajemen) yang secara khusus ditunjuk untuk menghasilakan informasi bagi pihak manajemen dan untuk mengambil keputusan [5].

Sistem Informasi berbasis E-learning ini merupakan hasil dari analisis dan observasi yang penulis lakukan terhadap sistem informasi yang sedang berjalan dan hasil perancangan yang baru dari perancangan Sistem Informasi Perkuliahan Online Pada Diploma-III Universitas Muhammadiyah Metro Kota Metro yang menggunakan database, dan menghasilkan sebuah antarmuka perkuliahan antara dosen dan mahasiswa [6].

Penulis [7], menjelaskan bahwa pengentasan masalah konseling bisa dimulai dari pengambilan keputusan dalam hidupnya untuk mewujudkan apa yang dicita-citakan di masa mendatang dengan rasa tanggung jawab, sehingga dapat menjalani hidup dan bertindak efektif, produktif, dan bahagia. Tujuan konseling bisa tercapai apabila konselor memiliki berbagai kompetensi yang dibutuhkan untuk membantu konseli, sehingga mandiri, cakap dan terampil. Sedangkan Pelayanan konseling adalah pekerjaan yang profesional, yang berarti pekerjaan atau kegiatan yang dilakukan oleh seseorang dan menjadi sumber penghasilan kehidupan yang memerlukan keahlian, kemahiran, atau kecakapan yang memenuhi standar mutu atau norma tertentu serta memerlukan pendidikan profesi.

Merujuk [8], proses tahapan dalam Konseling adalah : tahapan pengantaran, tahap investigasi, tahap intervensi, dan tahap penutup. Dalam sistem Informasi tahapan dalam konselingnya adalah 1) Tahap Pengantaran dalam Konseling, 2) Tahap Investigasi Masalah, 3) Tahap Intervensi Masalah dan Tahap Terakhir 4) Tahap Penutup (Simpulan) hasil setelah proses konseling. [8]

Upaya peningkatan bimbingan konseling pernah dilakukan oleh mahasiswa dengan menggunakan layanan sistem informasi konseling. Dalam penelitian ini melakukan penghitungan tingkat permasahan yang dihadapi oleh para mahasiswa. Bimbingan merupakan bantuan kepada individu dalam menghadapi persoalan-persoalan yang dapat timbul dalam diri mahasiswa. Dalam penilitian ini diperlukan suatu alur sistem informasi layanan konseling mahasiswa, gambar 1 merupakan alur diagram yang digunakan dalam merancang sistem informasi layanan konseling mahasiswa.

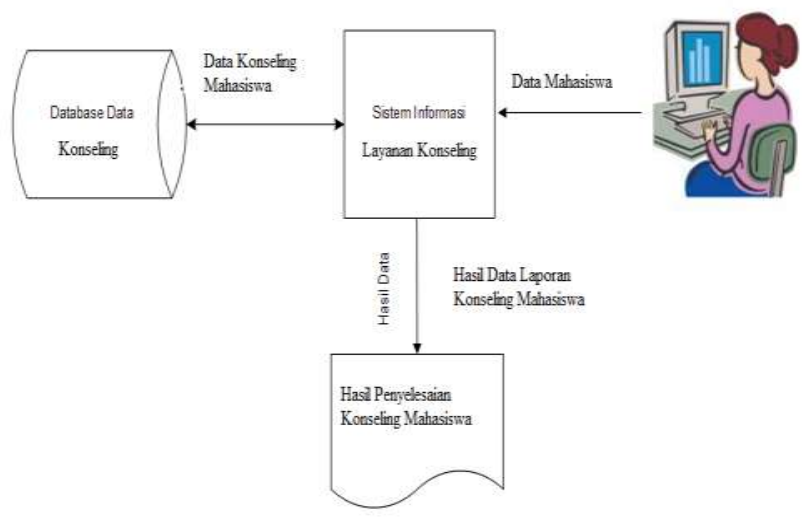

Gambar 1 Alur diagram sistem informasi layanan konseling mahasiswa 


\section{METODE}

\section{A. METOde PENELITIAN}

Metode dalam penelitian menggunakan Mix Method (Metode campuran) penggabungan antara kualitatif dan kuantitatif. Penelitian dilakukan dengan eksperimen terhadap mahasiswa program studi Bimbingan Konseling dan prodi Fakultas Ilmu Komputer Universitas Muhammadiyah Metro. Mahasiswa yang terlibat dalam implementasi model sebanyak 20 orang yang terbagi dalam 10 mahasiswa di program studi Bimbingan dan Konseling dan 10 mahasiswa di program studi ilmu komputer. Munculnya permasalahan yang terjadi kedua progam studi menggunakan eksperimen menggunakan model campur, sedangkan perkuliahan di kelas kontrol menggunakan layanan konseling berbasis sistem informasi. Tabel II menunjukkan tahapan yang dilakukan pada mahasiswa terhadap permasalahan yang dihadapi. Dalam metode sistem informasi yang digunakan dalam penelitian ini menggunakan metode kualitatif dalam pengambilan keputusan guna menghasilkan informasi Penelitian kualitatif adalah penelitian tentang riset yang bersifat deskriptif dan cenderung menggunakan analisis. Proses dan makna (perspektif subyek) lebih ditonjolkan dalam penelitian kualitatif. Landasan teori dimanfaatkan sebagai pemandu agar fokus penelitian sesuai dengan fakta di lapangan. Selain itu landasan teori juga bermanfaat untuk memberikan gambaran umum tentang latar penelitian dan sebagai bahan pembahasan hasil penelitian. [9]
Populasi penelitian adalah mahasiswa pendidikan pogram studi Bimbingan dan Konseling dan program studi ilmu komputer Universitas Muhammadiyah Metro Lampung berjumlah 20 orang yang mengambil Tahun Akademik 2017/2018. Teknik sampling yang digunakan adalah convenience sampling yaitu sistem penyampelan yang didasarkan atas pertimbangan kemudahan saja. Sampel penelitian tersebar dalam dua kelas. Satu kelas dipilih sebagai kelas eksperimen, dan kelas lainnya merupakan kelas kontrol. Desain yang digunakan dalam penelitian ini adalah nonequivalent control group design seperti ditunjukkan pada Tabel I. Simbol O pada Tabel I menunjukkan tes awal dan tes akhir, berfungsi untuk mengukur kemampuan awal dan akhir mahasiswa dalam keterampilan proses sains, X1 menunjukkan pembelajaran gelombang dan optik menggunakan model kegiatan laboratorium berbasis problem solving, dan X2 menunjukkan pembelajaran gelombang dan optik menggunakan model kegiatan laboratorium verifikasi.

TABEL I

DESAIN KONTROL PENELITIAN PROBLEM SOVLING MAHASISWA Kelas Tes Awal Perlakuan Tes Akhir

$\begin{array}{llll}\text { Eksperimen } & \mathrm{O} & \mathrm{X}_{1} & \mathrm{O}\end{array}$

$\begin{array}{llll}\text { Kontrol } & \mathrm{O} & \mathrm{X}_{2} & \mathrm{O}\end{array}$


TABEL II

PROBLEM SOLVING TERHADAP MAHASISWA

\begin{tabular}{|c|c|}
\hline Permasalahan & Proses Tahapan Konseling \\
\hline $\begin{array}{l}\text { Mahasiswa yang } \\
\text { mengalami } \\
\text { permasalahan } \\
\text { perekonomian }\end{array}$ & $\begin{array}{l}\text { 1)Tahap Pengantaran dalam } \\
\text { Konseling, 2) Tahap } \\
\text { Investigasi Masalah, 3) Tahap } \\
\text { Intervensi Masalah dan Tahap } \\
\text { Terakhir 4) Tahap Penutup } \\
\text { (Simpulan) hasil setelah proses } \\
\text { konseling. }\end{array}$ \\
\hline $\begin{array}{l}\text { Mahasiswa yang } \\
\text { malas dalam } \\
\text { menjalankan } \\
\text { perkuliahan }\end{array}$ & $\begin{array}{l}\text { 1)Tahap Pengantaran dalam } \\
\text { Konseling, 2) Tahap } \\
\text { Investigasi Masalah, 3) Tahap } \\
\text { Intervensi Masalah dan Tahap } \\
\text { Terakhir 4) Tahap Penutup } \\
\text { (Simpulan) hasil setelah proses } \\
\text { konseling. }\end{array}$ \\
\hline
\end{tabular}

\begin{tabular}{ll}
\hline $\begin{array}{l}\text { Permasalahan } \\
\text { hubungan keluarga } \\
\text { (orang tua) }\end{array}$ & $\begin{array}{l}\text { 1)Tahap Pengantaran dalam } \\
\text { Konseling, 2) Tahap } \\
\text { Investigasi Masalah, 3) Tahap } \\
\text { Intervensi Masalah dan Tahap } \\
\text { Terakhir 4) Tahap Penutup } \\
\text { (Simpulan) hasil setelah proses } \\
\text { konseling. }\end{array}$ \\
\hline $\begin{array}{l}\text { Permasalahan } \\
\text { kurang bersosialisasi } \\
\text { kampan lingkungan }\end{array}$ & $\begin{array}{l}\text { 1)Tahap Pengantaran dalam } \\
\text { Investigasi Masalah, 3) Tahap }\end{array}$ \\
& $\begin{array}{l}\text { Intervensi Masalah dan Tahap } \\
\text { Terakhir 4) Tahap Penutup } \\
\text { (Simpulan) hasil setelah proses } \\
\text { konseling. }\end{array}$ \\
\hline
\end{tabular}

Deskripsi Permasalahan
Mahasiswa menceritakan dan menjelaskan
permaslahan perokonomian yang terjadi,

rata-rata dari proses tahapan hasil

konseling yang dilakukan oleh Dosen

Prodi BK UM Metro bahwa mahasiswa

yang mengalami permasalahan ini banyak di kalangan orang tua mahasiswa bekerja buruh dan wiraswasta.

Mahasiswa menceritakan dan menjelaskan permaslahan yang terjadi, rata-rata dari proses tahapan hasil konseling yang dilakukan oleh Dosen Prodi BK UM Metro bahwa mahasiswa yang mengalami permasalahan ini ada beberapa faktor pemicu yaitu dari diri pribadi dan dari faktor lingkungan yaitu teman sebaya yang membuat mereka bersantai dan banyak membuang waktu untuk bermain, belum bisa memanajemen waktu dalam belajar.

Mahasiswa menceritakan dan menjelaskan permaslahan yang terjadi, rata-rata dari proses tahapan hasil konseling yang dilakukan oleh Dosen Prodi BK UM Metro bahwa mahasiswa yang mengalami permasalahan ini adalah mahasiswa yang mengalami broken home, orang tuanya Single Parent, dan tinggal dengan keluarga nenek kakek.

Mahasiswa menceritakan dan menjelaskan permaslahan yang terjadi, rata-rata dari proses tahapan hasil konseling yang dilakukan oleh Dosen Prodi BK UM Metro bahwa mahasiswa yang mengalami permasalahan ini adalah mahasiswa malu untuk bertanya, tidak suka bergaul, malas untuk berbicara dengan teman yang tidak di kenali.

\begin{tabular}{|c|c|c|c|c|}
\hline $\begin{array}{l}\text { Permasalahan } \\
\text { berhubungan dengan } \\
\text { lawan jenis }\end{array}$ & $\begin{array}{l}\text { 1)Tahap Pengantaran dalam } \\
\text { Konseling, 2) Tahap } \\
\text { Investigasi Masalah, 3) Tahap } \\
\text { Intervensi Masalah dan Tahap } \\
\text { Terakhir 4) Tahap Penutup } \\
\text { (Simpulan) hasil setelah proses } \\
\text { konseling. }\end{array}$ & $\begin{array}{l}\text { Mahasiswa menceritakan dan menjelaskan } \\
\text { permaslahan yang terjadi, rata-rata dari } \\
\text { proses tahapan hasil konseling yang } \\
\text { dilakukan oleh Dosen Prodi BK UM } \\
\text { Metro bahwa mahasiswa yang mengalami } \\
\text { permasalahan ini adalah mahasiswa yang } \\
\text { trauma karena sering patah hati, sering di } \\
\text { sakiti lawan jenis, sering di bohongi lawan } \\
\text { jenis, di duakan oleh lawan jenis } \\
\text { (selingkuh). }\end{array}$ & $\begin{array}{l}\text { Jumlah mahasiswa sebanyak } 3 \\
\text { orang dari } 20 \text { mahsiswa yang } \\
\text { menjadi model penelitian }\end{array}$ & $15 \%$ \\
\hline $\begin{array}{l}\text { Permasalahan } \\
\text { dengan Dosen }\end{array}$ & $\begin{array}{l}\text { 1)Tahap Pengantaran dalam } \\
\text { Konseling, 2) Tahap } \\
\text { Investigasi Masalah, 3) Tahap } \\
\text { Intervensi Masalah dan Tahap } \\
\text { Terakhir 4) Tahap Penutup } \\
\text { (Simpulan) hasil setelah proses } \\
\text { konseling. }\end{array}$ & $\begin{array}{l}\text { Mahasiswa menceritakan dan menjelaskan } \\
\text { permaslahan yang terjadi, rata-rata dari } \\
\text { proses tahapan hasil konseling yang } \\
\text { dilakukan oleh Dosen Prodi BK UM } \\
\text { Metro bahwa mahasiswa yang mengalami } \\
\text { permasalahan ini adalah mahasiswa yang } \\
\text { sering telat mengumpulkan tugas, jarang } \\
\text { masuk kelas (tidak disiplin). }\end{array}$ & $\begin{array}{l}\text { Jumlah mahasiswa sebanyak } 3 \\
\text { orang dari } 20 \text { mahsiswa yang } \\
\text { menjadi model penelitian }\end{array}$ & $15 \%$ \\
\hline
\end{tabular}

Sebelum dan sesudah problem solving terhadap mahasiswa yang terdiri dari 6 permasalahan yang sering terjadi dapat di uraian dengan koefisien reliabilitas sebesar sebagai berikut: Mahasiswa yang mengalami permasalahan perekonomian sebesar $30 \%$, mahasiswa yang malas dalam menjalankan perkuliahan sebesar $20 \%$, Permasalahan hubungan keluarga (orang tua) 10\%, Permasalahan kurang bersosialisasi dengan lingkungan kampus $10 \%$, Permasalahan berhubungan dengan lawan jenis $15 \%$, Permasalahan dengan Dosen 15\%. Berdasarkan permasalahan dan hasil-hasil penelitian yang telah dikemukakan, perlu dilakukan penelitian tentang penggunaan model Integrated Problem Solving Based 
Learning (IPSBL) guna mendapatkan data yang akan menjadi bahan kajian untuk bahan implimentasi aplikasi sistem informasi sebagai layanan konseling mahasiswa. Sebelum mahsiswa melakukan kegiatan dalam menyampaikan permaslahan melalui layanan sistem informasi konseling, maka dosen konseling perlu melakukan tahapan eksperimen menggunakan model IPSBL, tahapannya dapat dilihat pada Tabel III.

TABEL III.

MATRIKS TAHAPAN PROBLEM SOLVING INDIVIDU MAHASISWA DENGAN MODEL IPSBL

$\begin{array}{cc}\text { Tahapan } & \text { Deskripsi } \\ \text { Permasalaha } & \\ \text { n } & \end{array}$

\begin{tabular}{ll}
\hline Pendahuluan & - Dosen mengemukakan masalah yang harus \\
(Introduction & diselesaikan oleh setiap mahasiswa (individu), \\
) & eksperimen maupun perhitungan kuantitatif \\
& dengan masalah yang sering dihadapi oleh \\
& mahasiwa. \\
& Dosen melakukan semple 20 orang mahasiswa \\
& untuk menyelesaikan masalah yang diberikan \\
& tentang jenis dan penerapan analisis problem \\
& solving yang dihadapi mahasiswa secara \\
& kuantitatif \\
\hline Perencanaan & Mahasiswa mendefinisikan dan mengidentifikasi
\end{tabular}

(Planning) masalah yang tengah dihadapi, kemudian dosen mengkaji informasi ataupun literatur yang dibutuhkan, alat dan bahan apa yang diperlukan dalam hal ini merancang sebuah layanan sistem informasi guna menerima informasi problem solving mahasiswa.

\begin{tabular}{|c|c|}
\hline $\begin{array}{l}\text { Konfirmasi } \\
\text { (Confirmatio } \\
\text { n) }\end{array}$ & $\begin{array}{l}\text { - Mahasiswa mampu menyampaikan permasalahan } \\
\text { secara terbuka dan jujur melalui layanan sistem } \\
\text { informasi konseling. } \\
\text { - Mahasiswa menyiapkan pertanyaan-pertanyaan } \\
\text { sebelum melakukankonsultasi dengan dosen di } \\
\text { media sistem informasi layanan konseling. } \\
\text { - Mahasiswa melaksanakan apa yang menjadi } \\
\text { pembahasan dosen konseling, guna diterapkan } \\
\text { dikemudian hari setelah melakukan konsultasi } \\
\text { melalui media layanan sistem informasi } \\
\text { konseling. } \\
\text { - Mahasiswa memeriksa kembali } \\
\text { penyelesaian masalah yang telah dilakukannya } \\
\text { secara berkala. } \\
\text { - Mahasiswa mendiskusikan apa yang } \\
\text { diperolehnya baik dengan dosen, orang tua, orang } \\
\text { yang mampu memberikan masukan. } \\
\text { - Mahasiswa menuliskan hasil kajian teori analisis } \\
\text { menyangkut permasalahannya. } \\
\text { - Mahasiswa menuliskan hasil diskusi dengan } \\
\text { dosen konseling sebagai bahan analisis diri. } \\
\text { - Mahasiswa mempersiapkan diri untuk melakukan } \\
\text { perubahan yang lebih baik setelah menjalani } \\
\text { konseling dengan layanan sistem informasi . }\end{array}$ \\
\hline $\begin{array}{l}\text { Penilaian } \\
\text { (Evaluating) }\end{array}$ & $\begin{array}{l}\text { Mahasiswa melakukan perbaikan dirisecara } \\
\text { individu } \\
\text { Dosen melakukan penilaian kemampuan problem } \\
\text { solving dan kemampuan kognitif terhadap } \\
\text { mahasiwa yang telah melakukan konseling melalui } \\
\text { media layanan sistem informasi konseling. }\end{array}$ \\
\hline
\end{tabular}

Mahasiswa sebelum melakukan permasalahan melalui media layanan konseling berbasis sistem informasi, terlebih dahulu mahasiswa harus melakukan regestrasi identitas mahasiswa sangat dirahasiakan, hanya dosen pembimbing konseling dan mahasiswa yang bersangkutan saja.

\section{B. RANCANGAN METODE CAMPURAN}

Metode campuran yang digunakan adalah jenis Rancangan Campuran Paralel Konvergen. Menurut [10] dalam pendekatan ini, seseorang peneliti mengumpulkan data kuantitatif dan kualitatif, menganalisisnya secara terpisah, dan kemudian membandingkan hasil apakah temuan- temuan saling mengonfirmasi (lihat pada Gambar 2.) di bawah ini:

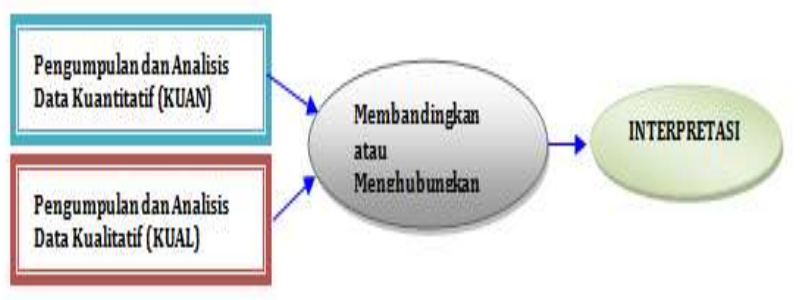

Gambar 2. Rancangan metode campuran paralel konvergen

\section{RANCANGAN METODE KUALITATIF SISTEM INFORMASI}

Penelitian kualitatif dalam Sistem Informasi (IS) melibatkan penggunaan data kualitatif, seperti wawancara, dokumen, dan data observasi peserta, untuk memahami dan menjelaskan fenomena sosial yang terjadi dilapangan.

\section{HASIL DAN PEMBAHASAN}

\section{A. HASIL}

Untuk menghasilkan data yang diinginkan, maka perlu dilakukan pembuatan tabel database dalam pengelompokan data mahasiswa yang menjadi model penelitian, Tabel IV merupakan tabel database mahasiswa. Tabel $\mathrm{V}$ merupakan bagian dari tabel database jenis konseling mahasiswa dalam layanan informasi konseling.

TABEL IV

IDENTITAS MAHASISWA DALAM SISTEM INFORMASI LAYANAN KONSELING MAHASISWA

\begin{tabular}{|c|c|c|c|c|c|}
\hline $\begin{array}{l}\mathbf{N} \\
\mathbf{0}\end{array}$ & Field Name & Data Type & $\begin{array}{c}\text { Field } \\
\text { Size }\end{array}$ & $\begin{array}{c}\text { Primary } \\
\text { Key }\end{array}$ & Description \\
\hline 1. & NIS & Int & 4 & Yes & $\begin{array}{c}\text { No Induk } \\
\text { Mhs }\end{array}$ \\
\hline 2. & Nama_Mhs & Varchar & 25 & - & Nama Mhs \\
\hline 3. & Kelas & Varchar & 4 & - & Kelas \\
\hline 4. & J_kelamin & Varchar & 15 & - & Jenis Kelamin \\
\hline 5. & Th_Angkatan & Varchar & 10 & - & $\begin{array}{c}\text { Tahun } \\
\text { Angkatan }\end{array}$ \\
\hline 6. & Tmt_lahir & Varchar & 50 & - & Tempat Lahir \\
\hline 7. & Tgl_lahir & Varchar & 25 & - & Tanggal Lahir \\
\hline 8. & Agama & Varchar & 15 & - & Agama Mhs \\
\hline 9. & Alamat & Varchar & 30 & - & Alamat Mhs \\
\hline 10. & Nama_ayah & Varchar & 25 & - & $\begin{array}{c}\text { Nama Ayah } \\
\text { Mhs }\end{array}$ \\
\hline 11. & Nama_ibu & Varchar & 25 & - & $\begin{array}{c}\text { Nama Ibu } \\
\text { Mhs }\end{array}$ \\
\hline
\end{tabular}


TABEL V

JENIS KONSELING MAHASISWA DALAM SISTEM INFORMAS

\begin{tabular}{clcccc}
\hline No & Field Name & $\begin{array}{c}\text { Data } \\
\text { Type }\end{array}$ & $\begin{array}{c}\text { Field } \\
\text { Size }\end{array}$ & $\begin{array}{c}\text { Primary } \\
\text { Key }\end{array}$ & $\begin{array}{c}\text { Descriptio } \\
\text { n }\end{array}$ \\
\hline 1 & Kd_Konseling & Varchar & 4 & Yes & $\begin{array}{c}\text { No } \\
\text { Konseling } \\
\text { Nama }\end{array}$ \\
2 & Jenis_Konseling & Varchar & 100 & - & $\begin{array}{c}\text { Konseling } \\
\text { Poin }\end{array}$ \\
3 & Poin & Int & 10 & - & $\begin{array}{c}\text { Penyelesaia } \\
\text { n }\end{array}$ \\
& Penyelesaian & Varchar & 100 & - &
\end{tabular}

Pada gambar 3. di bawah ini memperlihatkan bagaimana cara mahasiswa melakukan proses konseling melalui sistem informasi dapat dilihat di bawah ini proses login mahasiswa sebelum melakukan layanan konseling problem solving.

\section{Homepage}

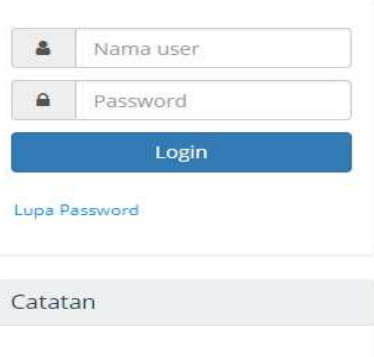

Pemberitahuan Login

Gambar. 3. Desain Rancangan login mahasiswa pada layanan konseling

Pada Gambar 4. Merupakan gambaran tampilan design konseling mahasiswa yang terdapat beberapa icon seperti home, note, chatting, calling, bell, emoticon, folder, profile mahasiswa pada bagian atas design sistem layanan informasi konseling mahasiswa problem solving.

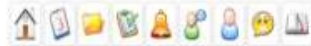

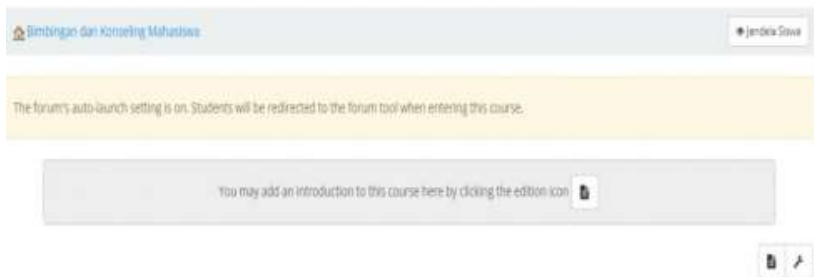

Gambar. 4. Desain tampilan bimbingan konseling mahasiswa

Pada Gambar 5. Tamplan profil mahasiswa ketika akan melakukan proses konseling dengan Dosen Bimbingan dan Konseling dengan cara klik bagian Course List pilih Bimbingan dan Konseling, yang akan dipilih untuk melakukan konseling problem solving.

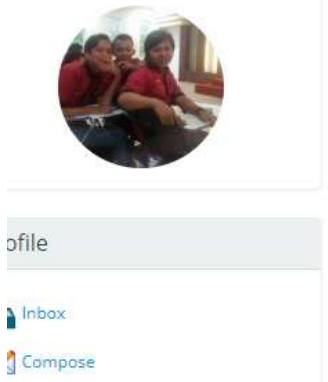

$\ll$ Kembali ke home page

Kategori

- Semester 1 (1 mata kuliah)

- Semester 2 (3 mata kuliah)

- Semester 4 (1 mata kuliah)

\section{Course list}

1 Compose

Bimbingan dan Konseling Mahasiswa

BIMBINGANDANKONSELINGMAHASISWA -

Gambar. 5. Tampilan mahsiswa yang melakukan bimbingan konseling

Pada gambar 6. Mahasiswa telah memilih Dosen Bimbingan dan Konseling untuk pelaksanaanKonseling Problem Solving dan pada gambar contoh yang diperlihatkan adalah mahasiswa memilih Dosen Bimbingan dan Konseling UM Metro yaitu adalah Hadi Pranoto, M.Pd di perlihatkan percakapan sebelum proses konseling berlangsung dan identitas di rahasiakan karena azas kerahasisaan dalam konseling itu di utamakan.

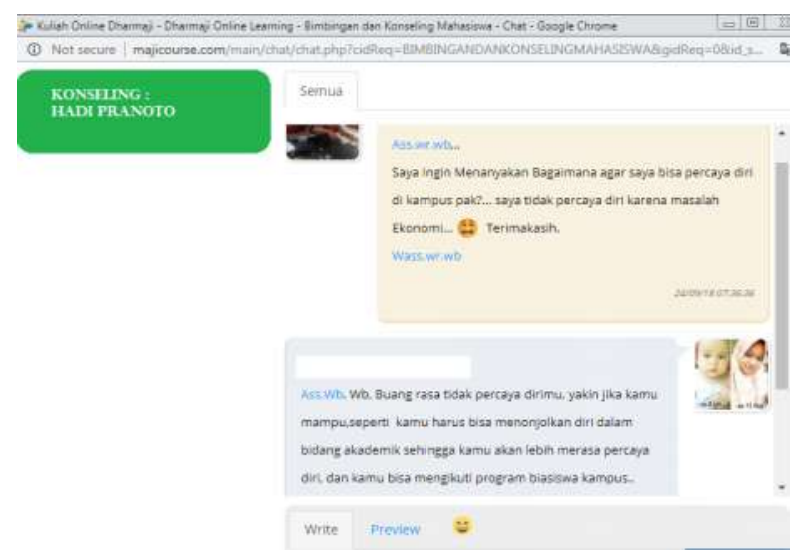

Gambar. 6. Tampilan layanan konseling mahasiswa dengan dosen konseling

Gambaran yang dialami subjek dari dua program studi

\section{Persentase Hasil Konseling Mahasiswa}
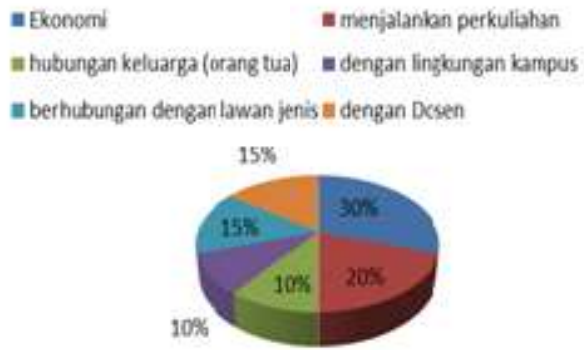

Gambar. 7. Grafik Presentase Hasil Konseling Mahasiswa dengan Layanan Sistem Informasi 
Tabel VI menunjukan progres dari hasil konseling mahasiswa dengan fasilitas layanan konseling berbasis sistem informasi.

TABEL VI

HASIL KONSELING MAHASISWA DENGAN LAYANAN SISTEM INFORMASI KONSELING

\begin{tabular}{|c|c|c|c|c|c|c|}
\hline \multicolumn{6}{|c|}{$\begin{array}{l}\text { Jumlah Mahasiswa dan Presentase (\%) } \\
\text { (Prodi BK dan Prodi Fikom) }\end{array}$} & \multirow[b]{2}{*}{$\begin{array}{l}\text { Total } \\
\text { Hasil }\end{array}$} \\
\hline $\begin{array}{l}\text { Ekono } \\
\mathrm{mi}\end{array}$ & $\begin{array}{l}\text { menjalan } \\
\text { kan } \\
\text { perkuliah } \\
\text { an }\end{array}$ & $\begin{array}{l}\text { Hub. } \\
\text { keluarga }\end{array}$ & $\begin{array}{l}\text { dengan } \\
\text { lingkun } \\
\text { gan } \\
\text { kampus }\end{array}$ & $\begin{array}{l}\text { Berhub. } \\
\text { dengan } \\
\text { lawan } \\
\text { jenis }\end{array}$ & $\begin{array}{l}\text { Dg. } \\
\text { Dosen }\end{array}$ & \\
\hline 6 & 4 & 2 & 2 & 3 & 3 & 20 \\
\hline
\end{tabular}

\begin{tabular}{lllllll}
\hline $30 \%$ & $20 \%$ & $10 \%$ & $10 \%$ & $15 \%$ & $15 \%$ & $100 \%$
\end{tabular}

Nampak terlihat gambaran secara umum dari permaslahan kedua subjek dari grafik dan tabel yang di paparkan di atas.

\section{Dampak psikologi yang dirasakan subjek}

Dampak yang terlihat adalah mahasiswa baik dari prodi BK UM Metro Maupun dari Prodi FIKOM UM Metro setelah melakukan proses konseling problem solving yang terintegrasi dengan sistem informasi mereka menjadi lebih percaya diri, dan mereka menjadi lebih memahami diri sendiri dan orang lain, menjadi pemberani dalam hal mengungkapkan pendapat, tidak takut dengan dosen untuk berkonsultasi dalam arahan membimbing baik akademik, sosial, belajar, karier dan lainya terkait permasalahan mahasiswa tersebut.

\section{Pengaruh konseling Problem Solving mahasiswa terhadap pemecahan masalah subjek}

Hasil analisis baik secara kuantitatif dan kualitatif menunjukkan bahwa subjek memberikan respon positif terhadap konseling mahasiswa berbasis sistem informasi. Subjek mengakui bahwa konseling layanan berbasis sistem informasi memberikan solusi atas permasalahan mahasiswa alami. Mereka merasakan keterbukaan ketika melaksanakan kegiatan proses konseling problem solving tersebut yang terintegrasi berbasis layanan sistem informasi. Mereka antusias dalam melakukan proses konseling pada setiap pertemuanya. Mereka menjadi lebih tertarik untuk melakukan proses konseling problem solving.Pengaruh yang sangat nampak adalah mereka dapat memecahkan permasalahan secara mandiri dan merasakan kenyamanan dalam konseling.

\section{B. PEMBAHASAN}

Berdasarkan Hasil Penelitian dapat dijelaskan bahwa pelaksanaan proses layanan konseling mahasiswa dapat membantu mahasiswa dalam memecahkan permasalahan secara mandiri sesuai dengan tahapan konseling. Dimana mahasiwa prodi Ilmu Komputer dan Prodi Bimbingan dan Konseling mereka dengan mudah mengakses sistem informasi layanan konseling mahasiswa dan dapat memilih Dosen Prodi BK untuk dijadikan sarana konseling permasalahan mahasiswa. dapat dilihat dari hasil konseling tersebut bahwa permaslahan yang di entaskan oleh Dosen BK salah satunya adalah Hadi Pranoto,M.Pd. Mahasiswa pada saat Proses Konseling melalui sistem informasi mereka menjelaskan permasalahan tentang 1) Ekonomi, 2) Keluarga, 3) Perkuliahan/Pembelajaran, 4) berhubungan dengan lawan jenis, 5) Berhubungan lingkungan kampus, dan 6) Masalah dengan Dosen.

Pembahasan tersebut masih perlu di gali lagi dalam proses konseling selanjutnya, karena banyak permasalahan mahasiswa yang kompleks sekali baik dalam bidang pribadi, sosial, belajar, karier, keluarga, keberagamaan, kewarganegaraan dan masih banyak lagi masalah yang perlu dientaskan di masa mendatang. Oleh sebab itu model layanan konseling mahasiswa dengan sistem informasi yang terintegrasi sangat membantu dan mempermudah mahasiswa dalam proses konseling yang tidak dilaksanakan secara tatap muka langsung (face to face). Karena tidak semua mahasiswa berani mengungkapkan permasalahanya secara langsung tatap muka. Mahasiswa dapat mengakses pada laman sistem informasi berikut ini: http://majicourse.com/courses/BIMBINGANDANKONSELI NGMAHASISWA sebelum melakukan proses konseling mahasiswa, mereka wajib login terlebih dahulu.

\section{KESIMPULAN}

Hasil analisis menunjukkan bahwa subjek memberikan respon positif terhadap konseling mahasiswa berbasis sistem informasi. Mahasiswa sebagai subjek mengakui bahwa konseling layanan berbasis sistem informasi memberikan solusi atas permasalahan mahasiswa yang mereka alami. Ini menunjukkan bahwa sistem layanan konseling mahasiswa dengan menggunakan teknologi memberikan pengaruh terhadap pemecahan masalah, disamping itu mahasiswa lebih nyaman dalam menyampaikan permasalahan yang tengah dihadapi.

\section{UCAPAN TERIMAKASIH}

Kami ingin mengucapkan terima kasih kepada Ketua Program Studi Bimbingan dan Konseling FKIP UM Metro dan Ketua Program Studi Ilmu Komputer FIKOM UM Metro yang telah memeberikan waktu dan kesempatan guna melaksanakan penelitian kepada mahasiswa.

\section{DAFTAR PUSTAKA}

[1] Dawkins, R. \& Wong, Y. (2016). A Piligrimage to the Dawn of Evolution. Library of Congress Cataloing in Publication Data Available: USA.

[2] Iskandar, A. (2017). Practical Problem Solving: Step by Step for Solving Problems. Publisher Elex Media Komputindo Country of Manufacture Indonesia Publish: Jakarta.

[3] Cardellini, L. (2006). Fostering Creative Problem Solving in Chemistry through Group Work. Chemistry Education Research and Practice, 7 (2): 131-140).

[4] Marzuki., Pranoto, H., Wibowo, A., \& Anjar, T. (2018). Penguasaan Keterampilan Dasar Menuju Konseling Efektif. Metro: Lemlit UMMetro Press.

[5] Kadir, A. (2003). Pengenalan Sistem Informasi. Andi: Jogjakarta.

[6] Sudarmaji, S. (2017). Migrasi dan Optimalisasi Database Sistem Informasi berbasis E-Learning Program Diploma III Manajemen 
Informatika Universitas Muhammadiyah Metro. MIKROTIK: Jurnal Manajemen Informatika, 6(2).

[7] Prayitno. (2009). Dasar-dasar Bimbingan dan Konseling. Jakarta: Rineka Cipta.

[8] Pranoto, H. \& Wibowo, A. (2018). Identifikasi Nilai Kearifan Lokal (Local Wisdom) Piil Pesenggiri Dan Perannya Dalam Dalam Pelayanan Konseling Lintas Budaya. JBKI (Jurnal Bimbingan Konseling Indonesia), 3(2), 36-42.

[9] Sutabri, T. (2005). Sistem Informasi Manajemen. Andi: Yogjakarta.

[10] Creswell, J. W. (2018). Research Design Pendekatan Metode Kualitatif, Kuantitatif, dan Campuran Edisi 4. Yogyakarta: Pustaka Pelajar. 